\title{
FORMATION OF NATIONAL CONSCIOUSNESS THROUGH TEACHING UZBEK FOLK APPLIED ART TO STUDENTS
}

\author{
Mehrali Kholisovich Yurdanidze \\ Lecturer, Department Of Fine Arts And Engineering Graphics, Andijan State University, Uzbekistan \\ Isroiljon Kadirjonovich Urinbayev \\ Lecturer, Department Of Fine Arts And Engineering Graphics, Andijan State University, Uzbekistan
}

\section{ABSTRACT}

The article gives a brief history of the development of folk arts and crafts, their stages and current significance. Besides the educational process, the students will study the folk arts and crafts, which are an integral part of our national cultural and spiritual heritage, as well as discuss the existing opportunities and shortcomings. It's done. Teaching students the applied decorative arts, their respect for the rich cultural and spiritual heritage of our people, the formation of our national identity in the minds of young people, their responsibility to preserve our increasingly forgotten values, contributes to the formation of.

KEYWORDS: - Applied decorative arts, applied arts, ceramics, painting, pottery, gold embroidery, embroidery, calligraphy, stylization, decorative.

\section{INTRODUCTION}

In the centuries-old history of the Uzbek people, folk arts and crafts are the most wonderful and popular part of our rich and colorful cultural heritage. The art forms that flourished in Uzbekistan are world-famous for their uniqueness and uniqueness. If we think about such stages of maturity and development, we will see that the roots of Uzbek applied arts go back to the childhood of mankind, that is, to primitive society.

Archaeological excavations of the territory of our country have revealed that the excavations of historical sites began in the Stone Age and have been going on for centuries.

Artistic thinking, which is an integral part of human consciousness, and, accordingly, artistic activity, have played an important role in the historical development of mankind. The resulting aesthetic and artistic cognition enabled people to recreate the world, its creatures, objects and events, and the shapes and colors of the environment in a variety of ways. This is how the creation of realistic and stylized images of shapes and colors came about, and it, in turn, began to take place in people's daily lives.

There are two types of styling: 
CURRENT RESEARCH JOURNAL OF PEDAGOGICS 2(12): 110-114,

December 2021 DOI: https://doi.org/10.37547/pedagogics-crjp-02-12-22

ISSN 2767-3278

(C)2021 Master Journals

Crossref doi) gil Google

Accepted $18^{\text {th }}$ December, 2021 \& Published $23^{\text {th }}$ December, 2021

1. Surface - implies the presence of a role model

with the spatial environment. or already created style elements.

2. Decorative - distinguished by its connection
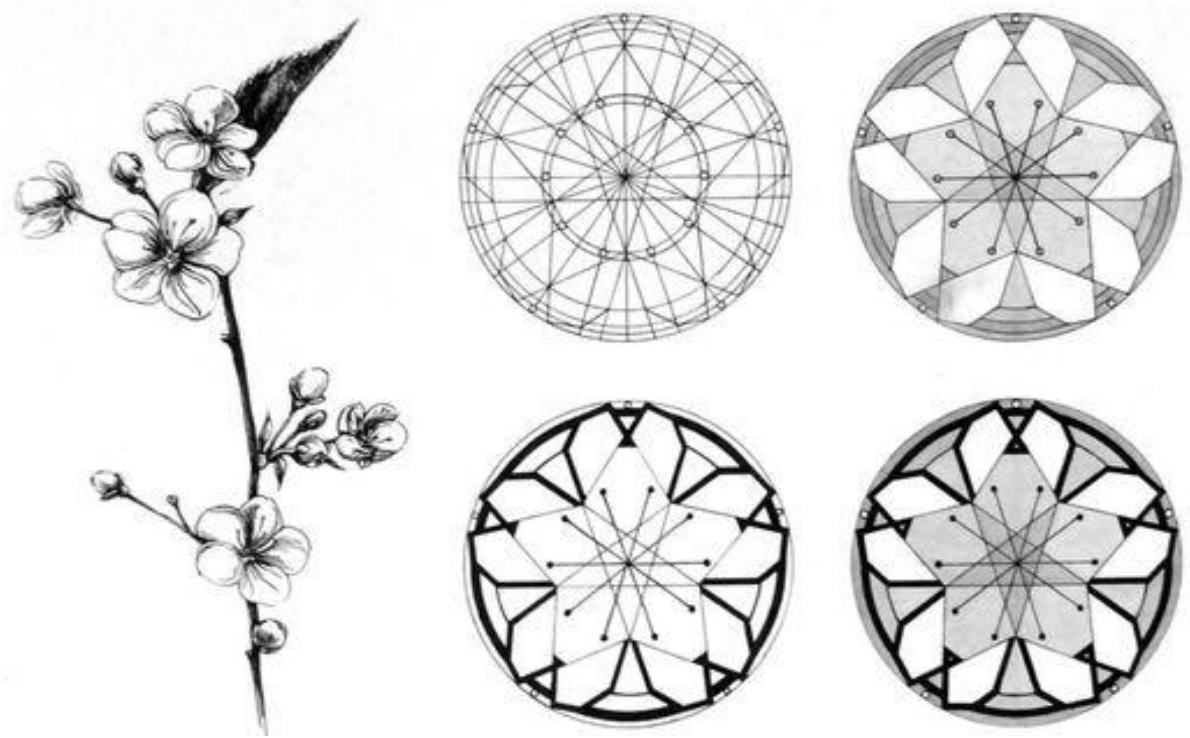

As a result, a variety of forms and types of artistic decorations have emerged. Among the surviving works of art of Uzbekistan and Central Asia, there are many works of art based on patterns.

There are certainly historical reasons such ornaments are more many and perfect than other arts.

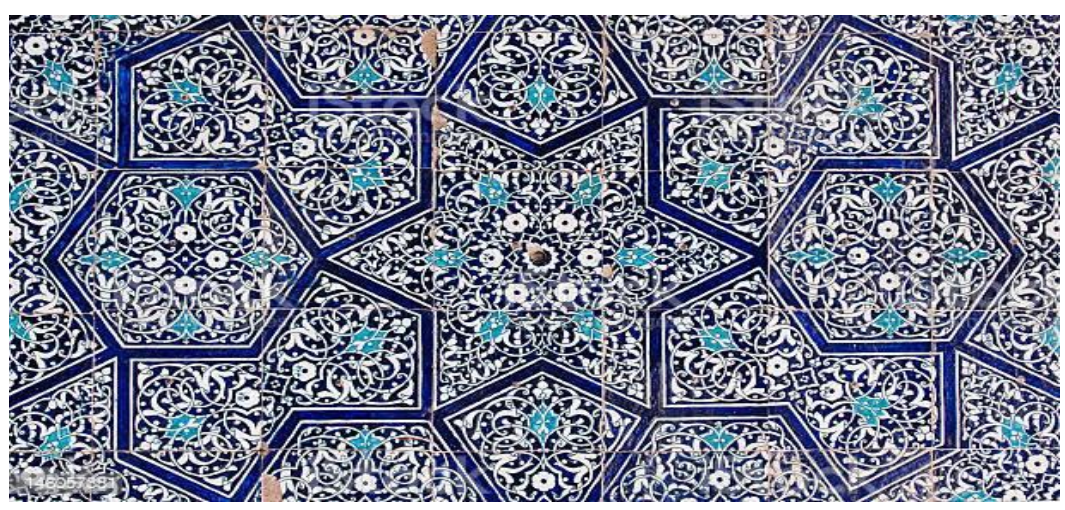


CURRENT RESEARCH JOURNAL OF PEDAGOGICS 2(12): 110-114,

December 2021 DOI: https://doi.org/10.37547/pedagogics-crjp-02-12-22

ISSN 2767-3278

(C)2021 Master Journals

Crossref dof 81 Google

Accepted $18^{\text {th }}$ December, 2021 \& Published 23 th December, 2021

Someone knew that in Islamic countries it is not customary to depict beings, because the creation of beings belongs only to Almighty God, and human beings are incapable of doing so. Getting to work is not crazy.

No image can rise to the level of being represented in it, so the image is false.

Because of such a deep, philosophical approach to fine arts, conditional styling and the creation of works of art based on symbolism have intensified.

This historical factor has led to the rapid development of the Uzbek national decorative art, which is now a world-famous architectural monument, which perfectly combines the art of pottery, tile, painting, calligraphy, stone carving and other arts.

The monuments of architecture and folk arts and crafts in Samarkand, Bukhara, Khiva, Shakhrisabz, Termez, Tashkent, Kokand and other cities are examples of harmonious, unique and historically invaluable works of art created by our past generations. And at the same time constitute the artistic and cultural masterpieces of world culture.

Folk decorative arts enrich the spiritual world of people, form a unique education based on the abundance of artistic taste, nurture the psyche. That is why Uzbek folk art is one of the most important sources for educating people in art, morality, humanity, shaping their worldview, and raising their cultural level. It is well known that all forms of art provide knowledge and nurture through the artistic, emotional, and spiritual influences they impart to their students, listeners, or spectators. At the same time, the qualities of applied decorative arts are very practical and unique and cannot be replaced by anything else. In other words, the fact that such works of art can perform both artistic and practical functions has led to their widespread popularity.

In the recent past, the most developed Uzbek applied decorative arts are pottery, painting, wood, stone and bone carving, carving, knitting, jewelry, embroidery, embroidery, carpet weaving, felt, basket weaving, weaving The unique performance technologies of such species, the real national names, their specific terms, the schools and styles of these arts, as well as the services of famous masters in these fields, were forgotten and endangered.

It is well known that the impact of the so-called "popular culture" on young people, which is becoming more and more widespread today in connection with the process of globalization, is given special attention, along with its pros and cons. One of the most troubling aspects of "popular culture" today is that it seeks to capture people's consciousness and thinking, to separate them from their age-old system of spiritual values, and to spread it. At the same time, "Popular culture" is characterized by the infiltration of moral and ethical vices, which are completely alien to human beings, as well as views and immoral works that contradict the ideas, historical and cultural traditions, oriental manners, and ethics of the peoples of the East. Today it poses a great threat to national cultures, to the understanding of national identity.

This is the case today with artists, folk masters, teachers and amateurs of the arts through the preservation of applied decorative arts, their comprehensive study and development, teaching the secrets of art to the younger generation. The preparation sets raising the aesthetic taste of the public, the cultural level of our people, especially our youth, to a higher level through the widespread promotion of works of art.

The work to achieve these goals is to create the most favorable conditions for folk masters, artists, to organize artistic education of young people, to master much art and to conduct them 
CURRENT RESEARCH JOURNAL OF PEDAGOGICS 2(12): 110-114,

December 2021 DOI: https://doi.org/10.37547/pedagogics-crjp-02-12-22

ISSN 2767-3278

(C)2021 Master Journals

Crossref do: 81 Google

Accepted $18^{\text {th }}$ December, 2021 \& Published 23 th December, 2021

in the right scientific and methodological direction. Organizing the training of artisteducators, to conduct relevant scientific research. However, because of insufficient attention paid to this issue in the regions, young people can be exposed to various iodine ideas, which can lead to an increase in crime among young people, and so on.

Forming aesthetic taste in the younger generation, imparting the necessary knowledge and moral education, developing labor, skills and abilities, choosing a profession and practical training tasks.

Circles organized in schools, palaces of culture, houses and student palaces are of special importance as centers of promotion of applied decorative arts, which are an integral part of our cultural heritage, but they are limited to this. It would be a big mistake to stay... Because the social networks, which are in demand today, also cover this area, if necessary, organize online clubs, introduce our young people to our national values through a new approach, by teaching them we need to help our nation understand its identity.

The unique educational and upbringing opportunities that result from the wide variety of Uzbek applied decorative arts are yielding results.

First of all, an individual can never fully master all kinds of applied decorative arts. However, an acquaintance at the general level is a necessary condition for an individual to reach a high cultural level. It follows that the teaching of these arts can take two forms: general theoretical knowledge or practical mastery of a type.

Interest in childhood can gradually become a lifelong profession, but in many cases, when we talk to parents or meet us, we are interested in some kind of art in our youth, but then for some reason Cases of leaving another profession will also be known. That's why we often see in their children that they want to achieve their childhood dreams through their children, to see in their children the goals that they could not achieve. In both cases, the role of the art world in the development of the individual is sufficiently fulfilled. Because in both cases there is an increase in aesthetic taste and cultural level.

The traditions of folk applied decorative art have been passed down from generation to generation over the centuries and are gaining a new stage of development in line with modern development, especially in modern urban architecture and building interiors. And can achieve higher results.

In conclusion, therefore the first of the five initiatives put forward by the President was aimed at increasing the interest of young people in music, painting, literature, theater, and other arts, to reveal their talents.

However, observations of these processes show that sometimes, the organizers, who do not understand the essence of the initiative, do not go beyond the superficiality of the report. We all know that it is impossible to achieve results without sufficient material and technical basis, for example, we can take, for example, art clubs organized in some secondary schools in the public education system. . Other education systems are no exception.

Thirty percent of the population is between 14 and 30 years old. Modern conditions and opportunities are being created for them to get an education and acquire a profession. At the same time, it is important to organize meaningful leisure time for young people. The more spiritually mature our youth are, the stronger their immunity against various alien diseases.

When the local art institutions, centers of applied arts, not only graduates but also masters of their field, both spiritually educating students and 
CURRENT RESEARCH JOURNAL OF PEDAGOGICS 2(12): 110-114,

December 2021 DOI: https://doi.org/10.37547/pedagogics-crjp-02-12-22

ISSN 2767-3278

(C)2021 Master Journals

Crossref do: 81 Google

Accepted 18 ${ }^{\text {th }}$ December, $2021 \&$ Published 23 $3^{\text {th }}$ December, 2021

teaching them all the secrets of applied arts. It will become increasingly difficult for us to achieve results without the involvement of experts who can provide them. And in this regard, attention is also paid to the issue of increasing the number of highly educated people in the field of music and art.

\section{REFERENCES}

1. Azimov I. O'zbekiston naqshu-nigoralari. T. G'G'ulom nomidagi adabiyot va san'at nashriyoti. 1987. $-132 \mathrm{~b}$.

2. Axmedov M. Yog'och o'ymakorligi. -T.: "Iqtisod-Moliya”, 2007.

3. Abduqodirov A. "Obidalar jilvasi". - T., "O'zbekiston" 1972 yil 64-b

4. Bulatov. S.S.O'zbek xalq amaliy be’zak san'ati. Toshkent.1991 yil.

5. Bulatov S.S., P.P. Shabaratov . M.A. Rasulov. "Naqqoshlik" "Iqtisod--Moliya" - 2010.

6. Bulatov S.S., P.P. Shabaratov N. A.
Mansurov. "Naqqoshlik" "Fan va texnologiya" - 2010. (uslubiy qo'llanma).

7. O'zbekiston milliy ensiklopediyasi. T.1-2.T., O‘zMU nashriyoti, 2000-2001.

8. O'zbekisgon Respublikasi Konstitutsiyasi. T., “O'zbekiston”, 1992.

9. O'zbekiston Respublikasining "Ta'lim to'g'risida"gi Qonuni. "Ma'rifat" gazetasi 1997-yil 1-oktabr.

10. Haqberdiyev, B. R. (2021). Oriental architectural monuments. the objectives and tasks of the course of designing architectural elements. ACADEMICIA: An International Multidisciplinary Research Journal, 11(7), 276-284.

11. Xalq badiiy hunarmandchiligi va amaliy san'atni yanada rivojlantirishning davlat yo'li bilan qo'llab-quvvatlash choratadbirlari to'grisida. O'zbekiston Respublikasi Prezidentining 1997 yil 31 mart farmoni "Xalq so'zi" gazetasi. Toshkent. 1997 yil 1 aprel. Karimov I.A. O'zbekiston: milliy istiqlol, iqtisod, siyosat, mafkura. 1-t. T.: O'zbekiston, 1996. 